\title{
КАНЦЕРОГЕННИЙ ВПЛИВ УЛЬТРАФІОЛЕТОВОГО ОПРОМІНЕННЯ НА ШКІРУ ЛЮДИНИ ЗА УМОВ МОБІЛЬНОСТІ НАСЕЛЕННЯ
}

\author{
Тернопільський національний медичний університет \\ імені І. Я. Горбачевського МОЗ України, м. Тернопіль, Україна
}

\begin{abstract}
Мета: на основі даних Національного канцер-реєстру проаналізувати захворюваність на меланому і рак шкіри в осіб молодого віку з обґрунтуванням канцерогенного впливу ультрафріолетового опромінення.

Матеріали і методи. У роботі використано статистичні дані з бюлетенів Національного канцер-реєстру України та власні клінічні спостереження. Проведено аналіз показників захворюваності у вікових групах від 20 до 44 років за період 2007-2019 рр. Здійснено порівняння показників захворюваності у когорті населення, яке у 2007-2008 рр. належало до вікової категорії 30-34 роки, а через 10 років (у 2018-2019 рр.) увійшло до вікової категорії 4044 роки.

Результати. Показано, що протягом десятирічного інтервалу відбулось зростання захворюваності на меланому в 2 рази, а на рак шкіри - в 4 рази. Враховуючи активну мобільність молодого населення в країни 3 високим ультрафріолетовим індексом сонячної активності, можна з високою ймовірністю вважати, що значна частка злоякісних пухлин шкіри була ініційована надмірним ультрафіолетовим опроміненням. Представлено клінічні приклади меланоми і раку шкіри, у виникненні яких ультрасріолетова радіація відіграла основну роль.

Висновки. Короткочасна міграція білого населення в екваторіальні широти спричиняє прискорене виникнення передракових локусів у шкірі молодих осіб під дією ультрафріолетової радіації. Транссрормація передракових уражень у злоякісні пухлини шкіри це тривалий процес, який на сьогодні можна ефективно контролювати візуальним самооглядом шкіри, цифрровим фотоскринінгом і телемедичними консультаціями з онкологами. Вчасні діагностика та лікування поверхневих форм злоякісної меланоми запобігають переходу її у фразу метастатичного поширення.
\end{abstract}

КЛЮчОВІ СЛОВА: меланома; рак шкіри; ультрафріолетовий індекс; захворюваність.

Географрічний ареал проживання українців перебуває в діапазоні 45-50 градусів північної широти (пн. ш.). Віками на території України були чітко виражені чотири пори року. Відповідно, сорормувались білошкірі люди з усіма генетичними особливостями. За останні 100 років географрічна мобільність нашого населення, нижча 45 градуса пн. ш., була незначною. У тоталітарному режимі Радянського Союзу українці примусово «мандрували» на 60-ту паралель і вище аж на Північне полярне коло, де обмороження було звичним явищем. 3 розвалом Союзу, починаючи з 1992 р., сотні тисяч українців виїхали на роботу в країни з інтенсивним ультрафріолетовим (УФ) опроміненням (Італія, Іспанія, США та ін.), які перебувають нижче 45 паралелі.

Тепер, з розвитком авіатуризму, сотні тисяч людей відвідують країни, що розташовані ближче до екватора, де ультрафріолетова радіація значно підвищена протягом цілого року. Взимку білошкірі європейці виїжджають на два тижні в екзотичні південні країни і буквально «смажаться» на сонці, набираючи додаткову ультрафріолетову радіацію, неприродну для них цієї пори року, збиваючи зимові генетичні налаштування. Якщо особа короткочасно змінює кліматичну зону і фрізично пристосовується до цього, то молекулярно-генетичні процеси, які відбуваються у шкірі білої людини, інколи негативно реагують на таку кліматичну мобільність. Особливо це стосується

(c) І. Й. Галайчук, 2021 осіб з кельтським, нордичним і середньоєвропейським фототипами шкіри (I, II і III типи за Фіцпатріком). На противагу їм, особи з V-VI фрототипами шкіри мають природний захист від УФ-променів завдяки інтенсивно пігментованій шкірі (населення екваторіальних широт) [17].

Ультрафіолетові хвилі - це один із найважливіших факторів навколишнього середовища, який впливає на організм людини. Діапазон УФ-хвиль поділяють на УФ-А (320-400 нм), УФ-В (280320 нм), УФ-С (100-280 нм). Найнебезпечнішими є хвилі УФ-С, які мають найкоротшу довжину, найвищу енергію, сильні мутагенні властивості, бактеріостатичну і бактерицидну дію. Однак вони майже повністю поглинаються озоновим шаром атмосорери. УФ-В хвилі складають 5-10 \% всього спектра УФ-випромінювання, яке досягає поверхні землі. Спричиняють найважливіші біологічні ефекти (сонячні опіки, пігментацію, синтез вітаміну $D_{3}$, імуносупресію і канцерогенний вплив). Хвилі УФ-В поглинаються хромофорами рогового шару шкіри. УФ-В безпосередньо ушкоджують ланцюги ДНК, що призводить до мутацій $[15,16]$.

Хвилі УФ-А мають найнижчу енергію, їх частка в загальному УФ-випромінюванні, що досягає землі, становить до 95 \%. УФ-А стимулюють вироблення набагато більше пігменту, аніж УФ-В хвилі. Мішенню їх канцерогенної дії $€$ меланоцити базального шару епідермісу або стовбурові клітини меланоми. УФ-А впливають на кровоносні судини і колагенові волокна, мають непрямий 
вплив на клітинну ДНК. Змінюючи структуру колагену і еластину, призводять до передчасного старіння шкіри. До процесу фоотостаріння 3 високим ризиком розвитку новоутворень найбільш схильні люди 3 I і II (меланодесіцитними) і III (меланокомпетентним) типами світлочутливості шкіри $[3,13,15,16]$.

Мета дослідження: на основі даних Національного канцер-реєстру проаналізувати захворюваність на меланому і рак шкіри в осіб молодого віку з обґрунтуванням канцерогенного впливу УФ-опромінення.

Матеріали і методи. У роботі використано статистичні дані 3 бюлетенів Національного канцер-реєстру України [6-11] та власні клінічні спостереження. Проведено аналіз показників захворюваності у вікових групах від 20 до 44 років за період 2007-2019 рр. Здійснено порівняння показників захворюваності у когорті населення, яке у 2007-2008 рр. належало до вікової категорії 30-34 роки, а через 10 років (у 2018-2019 рр.) увійшло до вікової категорії 40-44 роки.

Результати дослідження та їх обговорення. Меланома шкіри

Як серед чоловічого, так і серед жіночого населення захворюваність 3 віком поступово і неухильно зростає (табл. 1, 2). Для зіставлення даних вибрано показники захворюваності у вікових категоріях 30-34 роки і 40-44 роки за 2007-2008 і 2018-2019 рр. У чоловіків у 2007-2008 рр. показник захворюваності у віці 40-44 роки був більший у 1,5 раза, порівняно з чоловіками віком 3034 роки; аналогічне збільшення захворюваності у жінок - в 1,6 раза. Відповідно, у 2018-2019 рр. показники захворюваності у віці 40-44 роки були більшими в 2,6 раза у чоловіків та в 1,7 раза у жінок, аніж у віці 30-34 роки.

Показники захворюваності у віковій категорії 40-44 роки в 2018-2019 рр. зросли в 1,4 раза у чоловіків та в 1,2 раза у жінок, порівняно 3 показниками за 2007-2008 рр. (табл. 1, 2).

Таблиця 1. Захворюваність на меланому шкіри серед чоловіків (показник на 100 тис. чоловічого населення)

\begin{tabular}{|c|c|c|c|c|c|}
\hline \multirow{2}{*}{ Рік } & \multicolumn{5}{|c|}{ Вікові групи (роки) } \\
\cline { 2 - 6 } & $20-24$ & $25-29$ & $30-34$ & $35-39$ & $40-44$ \\
\hline 2019 & 1,3 & 1,3 & 2,5 & 3,2 & 5,1 \\
\hline 2018 & 1,1 & 1,6 & 2,1 & 3,7 & 6,7 \\
\hline 2016 & 0,9 & 1,0 & 3,4 & 4,0 & 6,4 \\
\hline 2011 & 1,4 & 1,5 & 3,0 & 3,8 & 4,6 \\
\hline 2008 & 0,8 & 1,2 & 2,6 & 3,5 & 4,0 \\
\hline 2007 & 0,9 & 1,0 & 3,0 & 2,7 & 4,3 \\
\hline
\end{tabular}

Зіставлення показників захворюваності в десятирічній динаміці. Когорта населення, яка у 2007-2008 рр. належала до вікової категорії 3034 роки, через 10 років (у 2018-2019 рр.) перейшла у вікову категорію 40-44 роки. Якщо у віці 30-34 роки (в 2007-2008 рр.) показники захворюваності були 2,6-3,0 у чоловіків і 3,5-4,1 у жінок, то у віці 40-44 роки (у 2018-2019 рр.) вони становили, відповідно, 5,1-6,7 у чоловіків і 7,0-8,0 у жінок, - тобто збільшились у 2,11 раза у чоловіків і в 1,97 раза у жінок. Ці дані цінні тим, що стосуються тієї самої когорти населення впродовж десятирічного статистичного інтервалу.

Таблиця 2. Захворюваність на меланому шкіри серед жінок (показник на 100 тис. жіночого населення)

\begin{tabular}{|c|c|c|c|c|c|}
\hline \multirow{2}{*}{ Рік } & \multicolumn{5}{|c|}{ Вікові групи (роки) } \\
\cline { 2 - 6 } & $20-24$ & $25-29$ & $30-34$ & $35-39$ & $40-44$ \\
\hline 2019 & 1,7 & 3,2 & 5,4 & 6,6 & 8,0 \\
\hline 2018 & 2,7 & 3,2 & 3,3 & 5,3 & 7,0 \\
\hline 2016 & 1,4 & 2,9 & 4,2 & 4,8 & 5,4 \\
\hline 2011 & 1,7 & 2,6 & 3,6 & 5,4 & 5,6 \\
\hline 2008 & 1,1 & 2,3 & 4,1 & 3,9 & 6,1 \\
\hline 2007 & 0,4 & 1,5 & 3,5 & 5,4 & 6,4 \\
\hline
\end{tabular}

Рак шкіри

За таким же алгоритмом проведено порівняльні розрахунки для показників захворюваності на рак шкіри. Захворюваність зростає разом 3 віком (табл. 3, 4). У 2007-2008 рр. у чоловіків віком 40-44 роки захворюваність була більшою в 3,9 раза, порівняно з віком 30-34 роки, а у жінок - в 2,9 раза. У 2018-2019 рр. показники захворюваності у віці 40-44 роки були більшими в 3,7 раза у чоловіків та в 3,5 раза у жінок, аніж у віці 30-34 роки.

Однак протягом десятиліття показники захворюваності у віковій категорії 40-44 роки були відносно стабільними: в 2018-2019 рр., порівняно 3 2007-2008 рр., зросли незначно - в 1,1 раза у чоловіків та в 1,3 раза у жінок (табл. 3,4 ).

\section{Таблиця 3. Захворюваність на рак шкіри серед чоловіків (показник на 100 тис. чоловічого населення)}

\begin{tabular}{|c|c|c|c|c|c|}
\hline \multirow{2}{*}{ Рік } & \multicolumn{5}{|c|}{ Вікові групи (роки) } \\
\cline { 2 - 6 } & $20-24$ & $25-29$ & $30-34$ & $35-39$ & $40-44$ \\
\hline 2019 & 2,3 & 1,3 & 2,6 & 5,8 & 13,1 \\
\hline 2018 & 0,6 & 1,9 & 3,7 & 5,6 & 10,2 \\
\hline 2016 & 1,0 & 1,2 & 3,2 & 6,1 & 12,3 \\
\hline 2011 & 1,2 & 1,6 & 2,3 & 6,2 & 10,0 \\
\hline 2008 & 0,7 & 1,1 & 3,3 & 5,2 & 10,2 \\
\hline 2007 & 0,8 & 1,3 & 2,1 & 5,6 & 10,8 \\
\hline
\end{tabular}

Таблиця 4. Захворюваність на рак шкіри серед жінок (показник на 100 тис. жіночого населення)

\begin{tabular}{|c|c|c|c|c|c|}
\hline \multirow{2}{*}{ Рік } & \multicolumn{5}{|c|}{ Вікові групи (роки) } \\
\cline { 2 - 6 } & $20-24$ & $25-29$ & $30-34$ & $35-39$ & $40-44$ \\
\hline 2019 & 1,0 & 1,7 & 3,2 & 7,5 & 11,7 \\
\hline 2018 & 0,4 & 1,8 & 4,3 & 5,8 & 14,5 \\
\hline 2016 & 0,5 & 1,6 & 4,2 & 7,1 & 14,0 \\
\hline 2011 & 0,7 & 1,8 & 2,8 & 5,0 & 11,3 \\
\hline 2008 & 0,5 & 1,2 & 3,9 & 6,0 & 9,8 \\
\hline 2007 & 0,8 & 1,7 & 2,7 & 6,0 & 9,7 \\
\hline
\end{tabular}

Зіставлення показників захворюваності когорти населення, яка у 2007-2008 рр. належала до вікової категорії 30-34 роки, з показниками через 10 років (за 2018-2019 рр.), коли ця когорта уві- 
йшла у вікову категорію 40-44 роки (табл. 3, 4). Якщо у віці 30-34 роки показники захворюваності були 2,1-3,3 у чоловіків і 2,7-3,9 у жінок, то в 40-44 роки ці показники становили, відповідно, 10,2-13,1 (чол.) і 11,7-14,5 (жін.), що свідчить про зростання захворюваності в 4,3 раза у чоловіків і в 4,0 раза у жінок.

Отже, порівняння показників однієї і тієї ж вікової когорти молодого населення 3 інтервалом у 10 років показало зростання захворюваності на меланому в 2 рази, а на рак шкіри - в 4 рази. Враховуючи молодий вік і мобільність цієї категорії населення, можна з високою ймовірністю вважати, що значна частка злоякісних пухлин шкіри була ініційована надмірним УФ-опроміненням. Зростання захворюваності на рак шкіри навіть у 4 рази не становить загрози для життя осіб віком 40-44 роки, тому що понад 99 \% випадків раку шкіри на сьогодні вдається вилікувати, чого не досягають при меланомі.

Які ж фрактори могли вплинути на зростання захворюваності в молодому віці? Насамперед це УФ-опромінення. Хоча старіння шкіри вже починається, однак у даному віці воно ще не відіграє ключову роль в канцерогенезі. Тому УФ-радіація для білошкірих осіб є основним ініціатором (тригером) у трансорормації звичайного невусу (родимки) в диспластичний, а диспластичного невусу в поверхневу меланому шкіри. Ультрафіолетові ушкодження ДНК і мутації в ключових генах, при недостатній протидії вторинних захисних механізмів, призводять до трансорормації і клональної проліферації кератиноцитів, що в підсумку клінічно маніфестує фрормуванням базальноклітинних і плоскоклітинних карцином $[3,16]$.

Люди у віці від 20 до 40 років належать до найбільш «географрічно» мобільної частини населення, саме вони в літні місяці найбільше часу проводять на відкритому повітрі та подорожують. За офріційною інфрормацією Державної служби статистики щодо туристичної діяльності туроператорів, турагентів і фрізичних осіб-підприємців, у 2011 р. понад 1,2 млн громадян України подорожували за кордон, а в 2017 р. ця циора зросла до 2,3 млн [14]. Найбільше туристів у 2017 р. було в Туреччині, Єгипті, Об'єднаних Арабських Еміратах, Греції (табл. 5) [14]. Проте це далеко не повний статистичний облік. Наприклад, інформаційне агентство «Інтерфракс-Україна» в лютому 2017 р. повідомило з посиланням на Міністерство закордонних справ Туреччини, що в 2016 р. країну відвідало 1 млн 250 тис. туристів з України.

Таблиця 5. Кількість громадян України, які подорожували та відпочивали за кордоном у $2017 \mathrm{p}$.

\begin{tabular}{|c|c|c|c|}
\hline Країна & $\begin{array}{c}\text { Кількість } \\
\text { туристів }\end{array}$ & Країна & $\begin{array}{c}\text { Кількість } \\
\text { туристів }\end{array}$ \\
\hline Греція & 49419 & Кіпр & 35998 \\
\hline Єгипет & 708262 & ОАЕ & 55943 \\
\hline Іспанія & 44572 & Таїланд & 20523 \\
\hline Італія & 28637 & Туреччина & 955463 \\
\hline
\end{tabular}

Таким чином, щороку сотні тисяч наших громадян перебувають деякий час у географічних широтах зі значно підвищеною УФ-радіацією. Для інтегральної оцінки впливу УФ-променів 3 1992 р. введено поняття ультрафріолетового індексу (УФІ) сонячної активності, що відображає можливість УФ-радіації спричиняти сонячні опіки шкіри. Наприклад, якщо у світлошкірої особи при УФІ=6 балів починаються опіки через 30 хв, то при УФІ=12 балів вона отримає опіки через 15 хв [12].

У середніх широтах УФІ наближається до небезпечних значень (6-7 балів) тільки при максимальній висоті Сонця над горизонтом (кінець червня - початок липня). На екваторі протягом року УФІ становить 9-11 балів. Значення УФІ вимірюють спектрорадіометрами або за допомогою математичних моделей і подають його разом з прогнозом погоди в усіх повідомленнях про погоду в інтернеті. У таблиці 6 відображено значення УФІ в один із весняних днів у Києві порівняно 3 містами, які знаходяться на географічній широті нижче 41-го градуса північної широти. Якщо у Києві УФІ становив від 1 до 3 балів, то в Барселоні, Дубаї, Гавані, Коломбо - 10-11 балів. Порівнюючи узагальнюючі значення УФ-індексів протягом року в Києві та Дубаї, констатуємо, що максимальний УФІ в Києві прирівнюється до мінімального УФІ в Дубаї, що становить 6 балів [18, 19].

\section{Таблиця 6. Показники ультрафіолетового індексу сонячної активності в різних містах північної півкулі на 17-18 квітня 2021 р.}

\begin{tabular}{|c|c|c|c|}
\hline \multirow{2}{*}{ Місто/країна } & \multicolumn{2}{|c|}{ УФІ (бали) } & \multirow{2}{*}{$\begin{array}{c}\text { Градус } \\
\text { північної } \\
\text { широти }\end{array}$} \\
\hline & 17.04 .2021 & 18.04 .2021 & \\
\hline Київ, Україна & 1 & $2-3$ & $50^{\circ} 27^{\prime}$ пн. ш. \\
\hline $\begin{array}{c}\text { Барселона, } \\
\text { Іспанія }\end{array}$ & 10 & 10 & $41^{\circ} 23^{\prime}$ пн. ш. \\
\hline $\begin{array}{c}\text { Єрусалим, } \\
\text { Ізраїль }\end{array}$ & 9 & 9 & $31^{\circ} 46^{\prime}$ пн. ш. \\
\hline Каїр, Єгипет & 8 & 9 & $30^{\circ} 03^{\prime}$ пн. ш. \\
\hline Дубай, OAE & 11 & 10 & $25^{\circ} 03^{\prime}$ пн. ш. \\
\hline Гавана, Куба & 10 & 10 & $23^{\circ} 07^{\prime}$ пн. ш. \\
\hline $\begin{array}{l}\text { Коломбо, } \\
\text { Шрі-Ланка }\end{array}$ & 10 & 11 & $6^{\circ} 55^{\prime}$ пн. ш. \\
\hline
\end{tabular}

Шкала УФІ має практичне значення для світлошкірих людей. Захист від УФ-опромінення потрібен при індексі від 3 балів (сонцезахисні окуляри і креми, одяг з довгими рукавами, кепки, перебування в тіні). При екстремальному УФІ в 11 і більше балів краще знаходитись в обідній час у приміщенні, а не на вулиці (пляжі) [12, 15-17].

Наслідки надмірного сонячного опромінення онкологи і дерматологи спостерігають щоосені. Однак не так просто діагностувати початкові прояви злоякісного росту та ще й пов'язати їх із УФ-опроміненням. Для цього необхідно ретельно зібрати анамнез, окрім клінічних методів, застосувати дерматоскопію і спектрофотометрію (при пігментних утвореннях), телемедичні консультації цифрових зображень підозрілих ділянок шкіри, цитологічні та гістологічні методи вери- 
фрікації. Нелегко також виявити особу з початковими проявами меланоми на стадії «іn situ» або Т1, такі люди просто не звертаються - їх нічого не турбує і взагалі вони не знають, що потрібно слідкувати за невусами (родимками) [2, 4, 5].

В офріційних канцер-реєстрах відображена статистика клінічних форм меланоми на стадіях T2, Т3, Т4 [1, 6-11]. Наприклад (див. табл. 2), серед жінок віком 30-34 роки лише 5,4 випадку меланоми на 100 тис. жіночого населення, у віці 40-44 роки - 8 випадків (дані 2019 р.). Це ніби зовсім небагато, однак не потрібно забувати, що на кожний клінічний випадок меланоми припадає 3-4 доклінічні випадки. Ось чому самоогляд поверхні шкіри з використанням правила ABCD, цифрова візуалізація фротоапаратом (телефоном) дрібних родимок до і після літньої відпустки $€$ дуже важливим моментом вчасного виявлення початкових передракових змін.

Клінічні приклади

На рисунку 1 - клінічне фото поверхневої меланоми $(6 \times 3,5$ мм) у жінки, 34 роки. Пігментне утворення виникло спонтанно через 4-6 місяців після літнього відпочинку в південній країні. Діагноз підтверджений гістологічно та імуногістохімічно після хірургічного видалення пухлини.

a

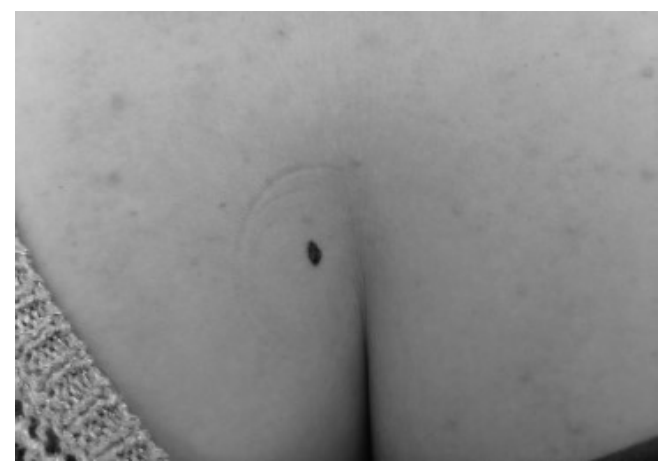

6

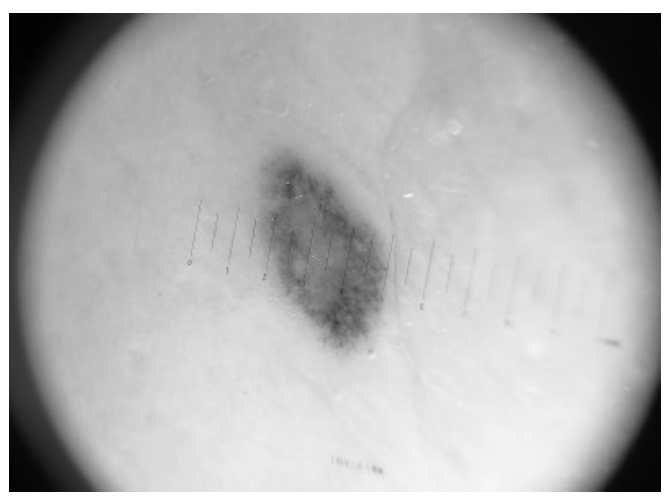

Рuc. 1. Клінічний приклад поверхневої меланоми у жінки: а) поверхневе пігментне утворення на шкірі в ділянці декольте; б) дерматоскопія, ×10 - симптом «голубої вуалі» та «обрубані» псевдоподії, що характерно для меланоми.

На рисунку 2 - клінічні прояви поверхневої меланоми (13×6,5 мм) шкіри спини у чоловіка, 42 роки. В анамнезі щорічні літні поїздки в південні країни. Меланома розвинулась на місці невеликої родимки. Діагноз підтверджений цитологічно та гістологічно. a

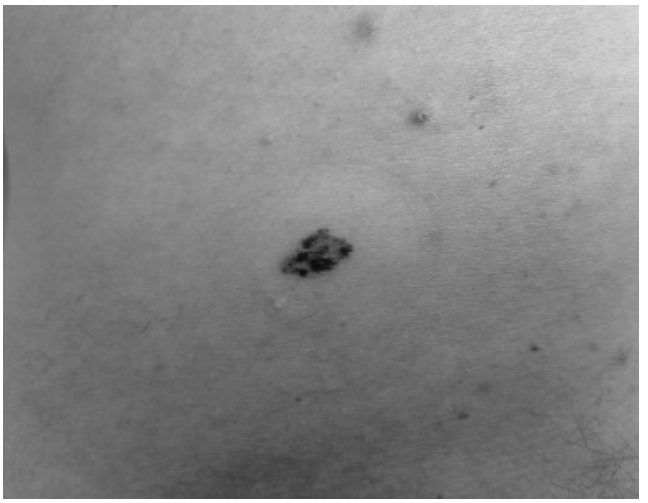

6

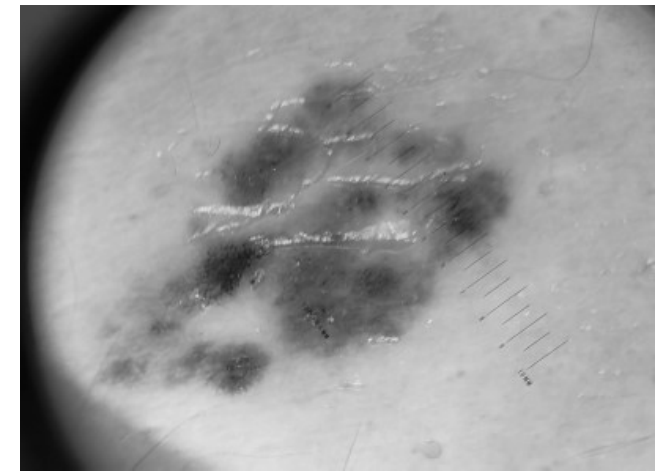

Рuc. 2. Клінічний прояв поверхневої меланоми у чоловіка на спині: а) асиметричне пігментне утворення 3 ділянками гіперпігментації і

депігментації; б) дерматоскопія, ×10 - кластери пігменту (гнізда меланоми), «голуба вуаль».

На рисунку 3 - клінічні ознаки поверхневого раку шкіри у жінки, 27 років. Під час засмаги ніколи не користувалась сонцезахисними кремами. Післяопераційне гістологічне дослідження підтвердило базальноклітинний рак шкіри.

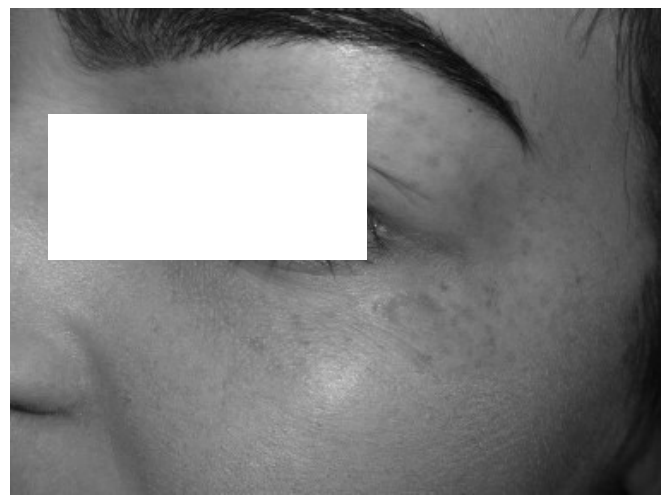

Puc. 3. На шкірі лівої щоки нижче зовнішнього кута ока візуалізується валикоподібне підвищення навколо ділянки пролабації шкіри, розмір ділянки 14×8 мм. Цитологічно - базаліома.

Таким чином, туристична мобільність значної частини молодого населення України у південні країни з високим УФ-індексом сонячної активності зобов'язує дотримуватись правил раціональної поведінки на відкритому повітрі з регулярним застосуванням фотозахисних засобів, щоб мінімізувати канцерогенний вплив УФ-радіації в осіб зі світлочутливою шкірою. 


\section{Висновки}

Короткочасна міграція білого населення в екваторіальні широти спричиняє прискорене виникнення передракових локусів у шкірі молодих осіб під дією УФ-радіації. Показник ультрафріолетового індексу сонячної активності необхідно враховувати для планування ефективного захисту від УФ-опромінення.

Трансформація передракових уражень у злоякісні пухлини шкіри це тривалий процес, який на сьогодні можна ефективно контролювати візуальним самооглядом шкіри, фротографічним скринінгом (за допомогою цифрових зображень) і телемедичними консультаціями зі спеціалістами (онкодерматологами, онкологами). Вчасні діагностика та лікування поверхневих фрорм злоякісної меланоми запобігають переходу її у фразу метастатичного поширення.

Перспективи подальших досліджень полягатимуть у вивченні порівняльної епідеміології злоякісних пухлин шкіри в Україні та країнах Центральної Європи, порівняно зі Скандинавськими країнами, за умов короткочасної кліматичної міграції в екваторіальні широти населення молодого віку з різними фототипами шкіри.

\section{Список літератури}

1. Грузєва Т. С. Особливості та тенденції захворюваності населення на злоякісні новоутворення шкіри / Т. С. Грузєва, Н. М. Калашникова // Вісник соціальної гігієни та організації охорони здоров'я України. - 2020. - № 4 (86). - С. 5-12. DOI: 10.11603/1681-2786.2020.4.11903

2. Галайчук І. Й. Неінвазивні методи діагностики меланоми шкіри / І. Й. Галайчук, О. С. Гоцко, І. В. Жулкевич // Вісник наукових досліджень. - 2015. - № 1. - С. 67-70.

3. Онкологія : підручник / Г. В. Бондар, А. І. Шевченко, І. Й. Галайчук, Ю. В. Думанський ; за ред. Г. В. Бондаря, А. І. Шевченка, І. И. Галайчука. - 2-ге вид., переробл. та доповн. - К. : ВСВ «Медицина», 2019. - 520 с.

4. Онкохірургічний і дерматологічний підходи до діагностики та лікувальної тактики у хворих на меланому шкіри / І. Й. Галайчук, Ш. Р. Бабанли, І. С. Данилків, Л. В. Шкробот // Клінічна онкологія. - 2014. - № 3 (15). - С. 41-44.

5. Пат. № 89831 України, МПК А61В 1/00, А61В 8/00, А61B 10/00. Спосіб дистанційної диференційної діагностики пігментних пухлин шкіри / І. Й. Галайчук, І. В. Жулкевич, О. С. Гоцко ; заявник і патентовласник Терноп. держ. мед. ун-т імені І. Я. Горбачевського. - № u 201315450 ; заявл. 30.12.13 ; опубл. 25.04.14, Бюл. № 8.

6. Рак в Україні, 2019-2020. Захворюваність, смертність, показники діяльності онкологічної служби [Електронний ресурс] / [3. П. Федоренко, Л. О. Гулак, Ю. Й. Михайлович та ін.] // Бюлетень Національного канцер-реєстру України. 2021. - № 22. - Режим доступу : http://www.ncru.inf.ua/publications/BULL_22/index.htm.

7. Рак в Україні, 2018-2019. Захворюваність, смертність, показники діяльності онкологічної служби [Електронний ресурс] / [3. П. Федоренко, Ю. И. Михайлович, Л. О. Гулак та ін.] // Бюлетень Національного канцер-реєстру України. 2020. - № 21. - Режим доступу : http://www.ncru.inf.ua/publications/BULL_21/index.htm.

8. Рак в Україні, 2016-2017. Захворюваність, смертність, показники діяльності онкологічної служби [Електронний ресурс] / [3. П. Федоренко, Л. О. Гулак, Ю. Й. Михайлович та ін.] // Бюлетень Національного канцер-реєстру України. 2018. - № 19. - Режим доступу : http://www.ncru.inf.ua/publications/BULL_19/index.htm.

9. Рак в Україні, 2011-2012. Захворюваність, смертність, показники діяльності онкологічної служби / [3. П. Федоренко, Ю. Й. Михайлович, Л. О. Гулак та ін.] // Бюлетень Національного канцер-реєстру України. - 2013. - № 14.

10. Рак в Україні, 2008-2009. Захворюваність, смертність, показники діяльності онкологічної служби/[3. П. Федоренко, А. В. Гайсенко, Л. О. Гулак та ін.] // Бюлетень Національного канцер-реєстру України. - 2010. - № 11.

11. Рак в Україні, 2007-2008. Захворюваність, смертність, показники діяльності онкологічної служби/[3. П. Федоренко, А. В. Гайсенко, Л. О. Гулак та ін.] // Бюлетень Національного канцер-реєстру України. - 2009. - № 10.

12. Стеблій Н. М. Ультрафріолетова складова інсоляції як фрактор ризику для здоров'я людини / Н. М. Стеблій, В. Я. Акіменко // Український журнал з проблем медицини праці. - 2019. - № 15 (1). - С. 35-45.

13. Снарская E. С. Фотоканцерогенез и профилактика рака кожи / Е. С. Снарская // Российский журнал кожных и венерических болезней. - 2012. - № 5. - С. 10-13.

14. Туристична діяльність в Україні у 2017 році : статистичний збірник. - К. : Державна служба статистики України, 2018. -90 c.

15. Photocarcinogenesis and skin cancer prevention strategies: an update / M. C. Martens, C. Seebode, J. Lehmann, S. Emmert // Anticancer Research. - 2018. - Vol. 38. - P. 1153-1158. DOI: 10.21873/anticanres.12334.

16. UV and Skin: Photocarcinogenesis / A. S. W. Oak, M. Athar, N. Yusuf, C. A. Elmets ; in: Krutmann J., Merk H. F., eds. - Environment and Skin : Springer International Publishing, Switzerland, 2018. - P. 67-103. - URL : https://doi. org/10.1007/978-3-319-43102-4_8.

17. Reddy P. S. Sunscreens: developments and challenges / P. S. Reddy, A. Sureshkumar, V. Jain // Int. J. App. Pharm. 2018. - Vol. 10 (6). - P. 54-59.

18. URL : https://www.meteonova.ru/uv-index/33345-Kiev.htm.

19. URL : https://www.weather-atlas.com/ru/united-arab-emirates/dubai-weather-march\#uv_index.

\section{References}

1.Gruzieva, T.S., \& Kalashnikova, N.M. (2020). Osoblyvosti ta tendentsii zakhvoriuvanosti naselennia na zloiakisni novoutvorennia shkiry [Peculiarities and trends in the skin malignancies morbidity]. Visnyk sotsialnoi hihiieny ta orhanizatsii 
okhorony zdorovia Ukrainy - Bulletin of Social Hygiene and Health Protection Organization of Ukraine, 4 (86), 5-12. DOI: 10.11603/1681-2786.2020.4.11903 [in Ukrainian].

2. Galaychuk, I.Y., Hotsko, O.S., \& Zhulkevych, I.V. (2015). Neinvazyvni metody diahnostyky melanomy shkiry [Noninvasive methods of skin melanoma detektion]. Visnyk naukovykh doslidzhen-Bulletin of Scientific Research, 1, 67-70 [in Ukrainian]. 3. Bondar, H.V., Shevchenko, A.I., Galaychuk, I.Y., \& Dumanskyi, Yu.V. (2019). Onkolohiya : pidruchnyk [Oncology: a textbook]. In: Bondar, H.V., Shevchenko, A.I., Galaychuk, I.Y. Eds. 2nd ed., rew. and add. Kyiv : Medicine [in Ukrainian].

4. Galaychuk, I.Y., Babanly, Sh.R., Danylkiv, I.S., \& Shkrobot, L.V. (2014). Onkokhirurhichnyi i dermatolohichnyi pidkhody do diahnostyky ta likuvalnoi taktyky u khvorykh na melanomu shkiry [Oncosurgical and dermatological approaches in diagnosis and treatment of patients with skin melanoma]. Klinichna onkolohiia - Clinical Oncology, 3 (15), $41-44$ [in Ukrainian].

5. Galaychuk, I.Y., Zhulkevych, I.V., \& Hotsko, O.S. (2014). Pat. Ukrainy, Sposib dystantsiinoi dyferentsiinoi diahnostyky pihmentnykh pukhlyn shkiry [Patent of Ukraine. Method of remote differential diagnosis of skin pigment tumors]. № 89831 MPK A61V 1/00, A61V 8/00, A61V 10/00 ; zaiavnyk i patentovlasnyk Ternop. derzh. med. un-t imeni I. Ya. Horbachevskoho. - № u 2013 15450; Zaiavl. 30.12.13 ; opubl. 25.04.14, Biul. № 8 - №. 89831 MPK A61V 1/00, A61V 8/00, A61V 10/00; applicant and patentowner I. Horbachevsky Ternopil State Med. Univ. -No. u 2013 15450; Applic.30.12.13; publ. 25.04.14, Bull. No. 8 [in Ukrainian].

6. Fedorenko, Z., Michailovich, Yu., Goulak, L., Gorokh, Ye., Ryzhov, A., Soumkina, O., \& Koutsenko, L. (2021). Rak v Ukraini, 2019-2020. Zakhvoriuvanist, smertnist, pokaznyky diialnosti onkolohichnoi sluzhby [Cancer in Ukraine, 20192020. Incidence, mortality, indicators for activities of the oncological service]. Biuleten Natsionalnoho kantser-reiestru Ukrainy - Bulletin of the National Cancer Registry of Ukraine, 22. Retrieved from: www.ncru.inf.ua/publications/BULL_22/ index.htm [in Ukrainian].

7. Fedorenko, Z.P., Hulak, L.O., Mykhailovych, Yu.Y., Horokh, Ye.L., Ryzhov, A.Yu., Sumkina, O.V., \& Kutsenko, L. (2020). Rak v Ukraini, 2018-2019. Zakhvoriuvanist, smertnist, pokaznyky diialnosti onkolohichnoi sluzhby [Cancer in Ukraine, 2018-2019. Incidence, mortality, indicators for activities of the oncological service]. Biuleten Natsionalnoho kantser-reiestru Ukrainy - Bulletin of the National Cancer Registry of Ukraine, 21. Retrieved from: http://www.ncru.inf.ua/publications/ BULL_21/index.htm [in Ukrainian].

8. Fedorenko, Z.P., Hulak, L.O., Mykhailovych, Yu.Y., Horokh, Ye.L., Ryzhov, A.Yu., Sumkina, O.V., \& Kutsenko, L. (2018). Rak v Ukraini, 2016-2017. Zakhvoriuvanist, smertnist, pokaznyky diialnosti onkolohichnoi sluzhby [Cancer in Ukraine, 2016-2017. Incidence, mortality, indicators for activities of the oncological service]. Biuleten Natsionalnoho kantserreiestru Ukrainy - Bulletin of the National Cancer Registry of Ukraine, 19. Retrieved from: www.ncru.inf.ua/publications/ BULL_19/index.htm [in Ukrainian].

9. Fedorenko, Z.P., Hulak, L.O., Mykhailovych, Yu.Y., Horokh, Ye.L., Ryzhov, A.Yu., Sumkina, O.V., \& Kutsenko, L. (2013). Rak v Ukraini, 2011-2012 Zakhvoriuvanist, smertnist, pokaznyky diialnosti onkolohichnoi sluzhby [Cancer in Ukraine, 2011-2012. Incidence, mortality, indicators for activities of the oncological service]. Biuleten Natsionalnoho kantser-reiestru Ukrainy - Bulletin of the National Cancer Registry of Ukraine, 14. [in Ukrainian].

10. Fedorenko, Z.P., Haysenko, A.V., \& Hulak, L.O. (2010). Rak v Ukraini, 2008-2009 Zakhvoriuvanist, smertnist, pokaznyky diialnosti onkolohichnoi sluzhby [Cancer in Ukraine, 2008-2009. Incidence, mortality, indicators for activities of the oncological service]. Biuleten Natsionalnoho kantser-reiestru Ukrainy - Bulletin of the National Cancer Registry of Ukraine, 11. [in Ukrainian].

11. Fedorenko, Z.P., Haysenko, A.V., \& Hulak, L.O. (2009). Rak v Ukraini, 2008-2009. Zakhvoriuvanist, smertnist, pokaznyky diialnosti onkolohichnoi sluzhby [Cancer in Ukraine, 2007-2008. Incidence, mortality, indicators for activities of the oncological service]. Biuleten Natsionalnoho kantser-reiestru Ukrainy - Bulletin of the National Cancer Registry of Ukraine, 10. [in Ukrainian].

12. Stebliy, N.M., \& Akimenko, V.Ya. (2019). Ultrafioletova skladova insoliatsii yak faktor ryzyku dlia zdorovia liudyny [Ultraviolet insulation component as a risk factor for human health]. Ukrainskyi zhurnal z problem medytsyny pratsi Ukrainian Journal of Occupational Health, 15 (1), 35-45. Retrieved from: https://doi.org/10.33573/ujoh2019.01.035 [in Ukrainian].

13. Snarskaya, E.S. (2012). Fotokantserogenez i profilaktika raka kozhi [Photocarcinogenesis and prevention of skin cancer]. Rossiyskiy zhurnal kozhnykh i venericheskikh bolezney - Russian Journal of Skin and Venereal Diseases, 5 , 10-13 [in Russian].

14. (2018). Turystychna diialnist v Ukraini u 2017 rotsi. Statystychnyy zbirnyk. [Tourist activity in Ukraine in 2017. Statistical collection]. Kyiv : Derzhavna sluzhba statystyky Ukrainy [in Ukrainian].

15. Martens, M.C., Seebode, C., Lehmann, J., \& Emmert, S. (2018). Photocarcinogenesis and skin cancer prevention strategies: an update. Anticancer Research, 38, 1153-1158. DOI: 10.21873/anticanres.12334.

16. Oak, A.S.W., Athar, M., Yusuf, N., \& Elmets, C.A. (2018). UV and Skin: photocarcinogenesis. In: Krutmann, J., Merk, H.F., Eds. Environment and Skin: Springer International Publishing, Switzerland. Retrieved from: https://doi. org/10.1007/978-3-319-43102-4_8.

17. Reddy, P.S., Sureshkumar, A., \& Jain, V. (2018). Sunscreens: developments and challenges. Int. J. App. Pharm., 10 (6), 54-59.

18. Retrieved from: https://www.meteonova.ru/uv-index/33345-Kiev.htm.

19. Retrieved from: https://www.weather-atlas.com/ru/united-arab-emirates/dubai-weather-march\#uv_index. 
CARCINOGENIC EFFECT OF ULTRAVIOLET IRRADIATION ON HUMAN SKIN IN THE CONDITIONS OF POPULATION MOBILITY

I. Y. Galaychuk

I. Horbachevsky Ternopil National Medical University, Ternopil, Ukraine

Purpose: to analyze the incidence of melanoma and skin cancer in young people with a justification for the carcinogenic effects of UV radiation based on the data of the National Cancer Registry.

Materials and Methods. The paper uses statistical data from the Bulletins of the National Cancer Registry of Ukraine [6-11] and own clinical observations. The analysis of cancer incidence in the age groups from 20 to 44 years for the period from 2007 to 2019 was carried out. A comparison of morbidity rates in the cohort of the population, which in 2007-2008 belonged to the age category of 30-34 years, and after 10 years (2018-2019), entered the age category of 40-44 years.

Results. It has been shown that during the 10-year interval there was a 2-fold increase in the incidence of melanoma and 4-fold increase in skin cancer. Given the active mobility of the young population to countries with a high ultraviolet index of solar activity, it can be assumed with a high probability that a significant proportion of malignant skin tumors were initiated by excessive UV radiation. Clinical examples of melanoma and skin cancer are presented, in the occurrence of which UV radiation played a major role.

Conclusions. Short-term migration of the white-skin population to equatorial latitudes contributes to the accelerated occurrence of premalignant loci in the skin of young people under the action of UV radiation. The transformation of precancerous lesions into malignant skin tumors is a long-term process that can now be effectively monitored by visual skin self-examinations, digital photoscreening, and telemedicine consultations with oncologists. Timely diagnosis and treatment of superficial forms of malignant melanoma prevents its transition to the phase of metastatic spreading.

KEY WORDS: melanoma; skin cancer; ultraviolet index; incidence.

Рукопис надійшов до редакції 01.09.2021 p.

Відомості про автора:

Галайчук Ігор Йосифович - доктор медичних наук, професор, завідувач кафедри онкології, променевої діагностики і терапії та радіаційної медицини Тернопільського національного медичного університету імені І. Я. Горбачевського МО3 України; тел.: +38(098) 648-83-16. 